\title{
Towards Contextual and Cultural Relevant Science Education in Non-Western Countries: The African Experience
}

\author{
John Fungulupembe Kalolo (PhD) \\ Mkwawa University College of Education \\ Faculty of Education, Psychology and Curriculum Studies Unit \\ Iringa, Tanzania \\ E-mail: mwakalolo@yahoo.ca
}

Received: Feb. 22, 2015 Accepted: March 23, 2015 Published: August 1, 2015

doi:10.5296/jse.v5i3.7147 URL: http://dx.doi.org/10.5296/jse.v5i3.7147

\begin{abstract}
Recent reforms of science education in the modern world have shown an increased need for culturally and contextually responsive science education in non-western countries. Despite the initiatives, there has been little discussion about the problems of irrelevance, ineffectiveness, and dis-functionality of western science education in non-western contexts, especially Africa.This review examines science education (SE) practices as experienced in non-western contexts. Drawing insights from context conscious science education traditions, the paper examines the link between the modern science education and the students' life worlds, in non-western contexts. It should be understood that this discussion is not about cultural change per se; rather, it is an engaging discussion focused at reimaging the western science to fit non-western frames of reference. Recognizing the need for relevant science education in non-western contexts, it is argued necessary to restructure science education in non-western contexts so that it exists within historical, cultural, and institutional contexts and that all western science education practices need to be examined to see whether they are better suited to non-western communities.
\end{abstract}

Keywords: Culturally relevant science education, Context relevant science education, Non-western context, Western science, Quality science education 


\section{Introduction}

For science education to be relevant to a specific context, it must take much more explicit account of the cultural context of the society which provides its setting, and whose needs it exists to serve (Wilson, 1981, pp. 29).

Despite Wilson's contention and initiatives to reform science education (SE), the actual status of modern SE in non-western contexts, especially Africa, has remained hegemonic, absolutist and universalistic. SE in Africa has been criticized in almost all African countries for lacking relevance to African cultures, being dominated by a collection of facts from 'western' science with little or no adaptation and with little practical utility, thus alienating its recipients from their environment (Porter \& Parvin, 2009). Sometimes western science is related to European and second world academic traditions and ways of knowing that are rooted in the renaissance and enlightenment and that exert considerable influence upon modern science and technology and, therefore, the shape of the technological society (Ellul, 1990). SE in today's classrooms has been blamed for being disconnected from learners' own lives, a depersonalized science, where there is no space for themselves or their ideas. Generally, the nature of SE in most non-western countries is still dominated by logical positivism with the imposition of Western values, beliefs, languages and epistemologies (Odora Hoppers, 2001). For decades SE in Africa has not taken into account the intellectual and cultural milieu of the children in non-western contexts. This trend has closed down the possibilities of reflecting on alternative ways of knowing and on other ontological perspectives. The need, therefore, has been to develop a culture and context sensitiveness within science education in non-western environments, especially Africa.

This paper examines the current state of SE in Africa and discusses the possibilities for, and implications of the current status of SE in non-western contexts. The author attempts to harness Afrocentric and Eurocentric views to develop SE best practices towards relevant SE in non-western contexts. The paper also takes the perspective that learning science among other things should start from learners' empirically based ways of knowing nature (Aikenhead \& Ogawa, 2007), not from the western scientific way of knowing nature, when considering the aspects of relevance of science education to the community. It is unfortunate that the two kinds of knowing (non-western and western) among learners in non-western contexts have been wrongly tried out, amalgamated and harmonized by SE stakeholders in non-western contexts (Ogawa, 1986, 2002). The paper paves a way to eschew knowledge, racism, ethnocentrism, domination and exploitation in African education systems. This is about reforming SE to reflect the cultural norms and contextual challenges of non-western societies and thus handing the power to indigenous communities to achieve mastery of their own environment.

The paper is developed under the following gaps in research knowledge that exist in SE:

- The need to view science as a culture within the cultural context of the students' frames of reference (Fensham, 2004; Ogawa, 1986).

- The need to acknowledge the contribution of non-western scientists. 
- The need to localize the science curriculum based on the students' daily lives.

- The need to study science in folk knowledge or native technologies.

- The need to bridge the students' traditional science knowledge and that of Western science with the use of indigenous science knowledge and the comparison of the relative epistemologies of the indigenous culture and modern science.

While the adaptation of science as a western cultural practice is necessary for non-western contexts, it is argued that it is necessary that all western SE practices need to be examined for their cultural and contextual appropriateness.

\section{Aim of the Study}

This paper rests on several interrelated premises grounded in the research, theory, and practice of other scholars in SE. These premises state that:

- Probably how non-western communities view SE in non-Western contexts is a result of the society being historically exploited, silenced, and their expectations and needs taken for granted in education (Davis \& Martin, 2008; Ogunniyi, 1988).

- Probably the non-western communities have given privileged status quo to dominant western voices, beliefs, ideologies, and views over the contextual voices of the society regarding the nature, goals of the SE offered (Tillman, 2002).

- Perhaps researchers' multiple and varied positions, roles, and identities that are embedded in the process and outcomes of SE have blinded us to not see other chances of looking at problems with African frames of reference (Chapman, 2007; Stanley, 2007).

In light of these premises, this paper presents a critical review ofselected literature by western and non-western SE researchers from the 1980s to the present, and identifies the culturally and contextually relevant SE framework for non-western contexts, especially Africa. The specific questions addressed in this article include the following:

- What is the nature of western science as experienced in the non-western world?

- To what extent have efforts to promote scientific literacy in non-western nations inadvertently and unnecessarily promoted a western, or otherwise, alien cultural view point?

- What impacts does western SE have on SE practices in the non-western world?

- How could SE best be addressed to reflect the realities of non-western contexts? (i.e., what could be the ideal cultural and contextual science education frameworks for non-western learners in the modern world?)

The selection of the literature to be reviewed was based on its ability to answer the outlined guiding questions of the study.

\section{Context of the study}

The research area for this paper is the world of formal SE for non-western communities. This world of interest is situated in three very different contexts: western science education 
occurring in non-western cultural contexts; western SE in a western context, but with populations of predominantly non-western origin (for example, aboriginal populations); and western science education in a western context but with populations of varied cultural origin, in both western and non-western countries that are addressed as developing countries. In each of these locations the concern has been voiced since the early 1980s about the outcomes of formal SE, particularly the SE of indigenous communities. In order to address this concern, it was therefore considered important to analyze and interpret the experiences critically in the provision of formal SE for non-western communities.

\section{Methodology}

In addressing the topic at hand, two major data sources were employed:

- Researcher's personal experiences: My previous experiences in the African context drew my attention to a problem that I refer to as educational domination. Personal experience methods demand the acknowledgement of the researcher's own experiences - their own tellings, livings, relivings and retellings. It is quite important, among other things, to understand why most non-western countries have been struggling with curricula that are seen as clearly foreign to their own cultural experience.

- An Integrative Research Review. In order to ensure some structure in the analysis of published data I adopted the Integrative Research Review technique, as described by Cooper (1982), as a tool to explore and analyze the written discourse about SE in non-western cultures. The discourse was accessed from the $1980 \mathrm{~s}$ to date through published papers and journal articles, all of which represent a distillation of the author's experience in analyzing the trend of SE in non-western contexts. The author attempted to interpret not only the content, but also the context of each piece of research. In so doing, I have viewed researchers as my informants and their published works as their 'field texts' (Clandinin, 1993).

The detailed analysis of western SE is presented in the sections that follow.

\section{Nature of western $\mathrm{SE}$ as practiced in non-western world}

Science originated from Europe and later expanded with European culture to the present day western world (Ogawa, 1989). Modern science, as it is called, connotes two ideas. First, it distinguishes itself from uncivilized and ancient science and relies on a hypothetical, deductive, experimental undertaking which uses objectivity to explain reality. Western science is therefore seen as the only correct path to knowledge acquisition in popular western culture. Second, it serves to separate the western way of thinking (which, in fact follows scientific reasoning) from so-called primitive thinking represented by traditional, usually non-western forms of thought.

Science educators have for a long time viewed western SE as one of several aspects of culture and thus it has been appropriate to speak of the western context because the west is the historic home of modern science, in the sense of a hypothetical-deductive, experimental approach to science (Cobern, 1998; Ogawa, 1986). The teaching of modem science in Africa 
began when western education was introduced into the continent during the last half of the nineteenth century. While Garrison and Bentley (1990, p. 188) called the decade of the 1950s and 1960s the "golden era" of North American and European science education curriculum development, Prather (1990) named it a "revolution in science education" (pp. 12). In this period, UNESCO and other governmental agencies arranged for the transfer of many of these curriculum developments to non-western, Third World nations to aid technological development and modernization. The prevailing attitude towards the transfer of scientific knowledge paid little heed to the context and culture of the host non-western countries. This marked the beginning of substituting the non-western scientific explanations of everyday events such as death, disease, and disaster, with western scientific explanations. In this way, modern science was seen by the indigenous people as an alien knowledge, brought into developing societies to displace non-scientific ideas. Since then, SE has been characterized by logical positivism, with the imposition of western values, beliefs, languages and epistemologies (Odora-Hoppers, 2001). However, with the advent of political independence in the late 1950s and the early 1960s, most countries in Africa realized that the type of science being taught in schools was not compatible with their cultural and contextual needs and aspirations.

The advent of cultural sensitiveness within SE, where the idea of western science being one of sub-cultures in the western tradition is shared, can be traced back to Maddock's (1981) memorable review article, "science education: An anthropological viewpoint". Before that, most science educators had identified cultural and linguistic hazards and problems prohibiting effective science teaching in non-western societies (Wilson, 1981). For decades, $\mathrm{SE}$ in non-western countries has been dominated by western science. This has allowed the western intellectual traditions and practitioners to write themselves into the past, present and future of Africa as civilizers, saviours, initiators, mentors, and arbiters (Magubane, 2004; Mbembe, 2001). This has created a wide gap between the needs of non-western society in their respective countries and the level of scientific and technological competence available to meet their needs. Many science educators and practitioners have been challenging this type of education by calling for reforms to develop SE in a way that would help to make it more relevant and useful for learners in non-western contexts as anticipated by the stakeholders (Fensham, 2004; Holbrook, 2003; Sjøberg, 2002).

Throughout this paper the author uses the term relevant/relevance to mean something valuable, meaningful and/or useful for students. In the context of learning, relevance implies a learning process that occurs in the learner's context of reference and/or judged from their point of view (Holbrook, 2010). It is like situated learning where learning takes place within an appropriate social context (Lave \&Wenger, 1990; McLellan, 1995). On the other hand, the term western science as used in this paper refers to SE ideas and practices whose origins can be traced from the European traditions of knowing, teaching and learning. I use western science to depict specific western norms, values, beliefs, language, expectations, technologies, and conservative actions (Cobern \& Loving, 2001; Snively \& Corsiglia, 2001; Stanley \& Brickhouse, 2001).The term 'non-western community as used in this paper refers to people or cultures that are native to specific non-western contexts. The term science education has been 
used to mean the teaching and learning of Western scientific ideas and skills in the context of a formal education system. In other words, SE takes place whenever schools and teachers attempt to introduce students to scientific explanations and concepts as part of a formal school curriculum. As pointed out by Ogawa (1995), SE as discussed in this paper includes personal science (the result of personal beliefs and experiences with nature), indigenous science (the communal beliefs and experiences of a micro culture or culture, knowledge which may or may not converge with one's personal science), and western modern science.

\section{Relevance of science education}

Contextually and culturally relevant SE can relate to the kind of education that establishes the usefulness of what is taught in real-life examples, relating material to everyday applications, drawing cases from current newsworthy issues, giving local examples (establishing relevance to local cases) and relating theory to practice (how theory can be applied in practice) (Kember \& McNaught, 2007). This would enable students to see how the subjects fit together and contribute eventually to competency in their discipline or profession. Gay (2000) describes culturally and contextually responsive education as having the following characteristics:

- Acknowledges the legitimacy of the cultural heritages of different ethnic groups, both as legacies that affect students' dispositions, attitudes, and approaches to learning and as worthy content to be taught in the formal curriculum.

- Builds bridges of meaningfulness between home and school experiences as well as between academic abstractions and lived sociocultural realities.

- Uses a wide variety of instructional strategies that are connected to different learning styles.

- Teaches students to know and praise their own and each other's cultural heritages.

- Incorporates multicultural information, resources, and materials in all the subjects and skills routinely taught in schools. (p. 29)

Despite Gay's contention and other scholars' initiatives to reform SE towards contextual and cultural demands, international studies have shown that school science in today's non-western schools has been becoming more unpopular and uninteresting among students (Holbrook, 2003; Osborne \& Collins, 2001; Sjøberg \& Schreiner, 2002). Students seem to be motivated to learn if the science content is interesting, useful for their lives and future development, and connected with their cultural and contextual everyday life (Dawson, 2000; Osborne, Ratcliffe, Collins, Millar, \& Duschl, 2003). The last international ICASE 2003 World Conference in Science and Technology Education, held in Penang, Malaysia recognized the critical need to increase relevance in SE through three main areas: relevance to the perceived needs and interests of the student; relevance to industry, or student careers; and relevance to the needs of society, or the culture (ICASE, 2003).

This need has stimulated science educators to improve the cultural and contextual relevance of SE for the following major reasons: first, to encompass facets of cultural and contextual 
knowledge; secondly, to enhance the sovereignty and cultural survival (a process of healing and rebuilding Indigenous nations oppressed by colonization) (McKinley, 2007); thirdly, to achieve a science education system that is both contextually and cultural relevant to the communities in non-western contexts and especially students whose cultures and languages differ from the predominant Eurocentric culture and language of science. These reasons are the three broad topics around which this article is organized.

\section{Features of western science as identified from nonwestern contexts}

Western science (like traditional culture) has its own values, norms, practices, and beliefs and is therefore a culture in its own right (Davis \& Martin, 2008). In the non-western context, western science has been seen to focus on received knowledge which is dominated by Eurocentric thought. Hence, the focus has too often been on giving the right answers versus problem posing and solving (Freire, 1999).SE researchers and educators have elaborated the causes for the present state of SE in non-western contexts (Anamuah-Mensah, Mereku, \& Ameyaw-Asabere, 2004; Fredua-Kwarteng \&Ahia, 2005). These causes include:

\subsection{Alienating effect of western science.}

This is a practice whereby western science isolates non-western communities from their own contexts and cultures (Maddock, 1983). Maddock relates this situation to the lack of originality of western science in the non-western contexts. As such the non-western communities identify the western science as being characterized with a displacing impact whereby the local people's ways of knowing are being replaced with western ways of knowing, a situation which has resulted to making SE being disconnected from nonwesterners' everyday lives. Such alienating effect of western science is also aggravated by the continuous use of western science textbooks in non-western classrooms, a situation which has increased dependence on knowledge and technology from the western world (Davis \& Martin, 2008; Ryan, 2008).

\subsection{Distracting effect of western science.}

This is a practice whereby the colonisers divert the attention of the non-westerners (colonised) from real issues in science and things that matter to their contexts to issues that are not important (Nyamnjoh, 2012). Even when there is evidence showing that such attentions are not important in the non-western contexts, they are forced to continue celebrating them. An example of this practice is a continuous use of western science curricula, even when they are proven as being not context responsive, unintelligible, ambiguous and chaotic in their implementation (Dei, 2012; Sifuna 2007).

Not only does western science possess such a distracting effect but also it celebrates uniformitarianism, a practice which demands all scientific constructs to be applied consistently throughout the world (Stanley \& Brickhouse, 2001). This presumption disregards the contextual and cultural differences that exist between western and non-western worlds. The knowledge based on this presumption also seems to be contested by non-westerners who demand knowledge applicability and contextual responsiveness in schooling (Roth \& Lee, 2004; Ryder, 2001). 


\subsection{Dogmatizing the western science.}

This is a situation whereby despite the differences in contexts, culture and science audience, western SE is presented as dogmatic and a prescribed correct and unchanging truth with the only correct epistemological grounding for understanding the world (Aikenhead \& Ogawa, 2007; Ogunniyi, 1988). Fleer (2008) contends that there are a number of dominant frameworks in SE and though they have been used for a number of decades in non-western contexts without fruitful outcomes, no attempt has been made to query their fundamental realities, hidden agendas or their applicability. For example, the issues of content structure and focus of SE in Tanzanian secondary schools is a critical issue, yet the Ministry of Education and the partner ministries in education have not provided an opportunity for the public to question their authenticity. The unspoken reality is that non-western education systems have failed to hold their own positions because of pressure from the western countries, who would not want certain liberative entities to be included in education thereby compromising their territories (Anzaldua, 1999).

\subsection{Supremacy impact of western science.}

This is a practice whereby SE in non-western contexts has failed to blend with non-western experiences, leading to a situation where it is now considered as alien knowledge originating from the west. The originality of western SE described in this sub-section does not lie in the appropriation of western thought per se, but rather, lies in the forceful, uncritical, discriminating and imitative identity that western knowledge presents over non-western science during meaning making (Knamiller, 1984; Lave \& Wenger, 1991).

This is to say the relationship between western and non-western SE has been poorly articulated, resulting in the inapplicability of most western science theories, concepts or models in non-western contexts (Fleer, 2008). For example, topics that relate to mechanized farming, control of malaria and many tropical diseases, ecological balance, provision of good and safe water, food preservation, development of good roads, solving the problems related to drought, small agro-based industries are likely to be more relevant to African settings than topics such as computer-assisted learning, laser beams, radio activity and many other topics that have been introduced into Tanzanian curricula.

\subsection{Forced importation of western SE.}

This is a situation whereby non-westerners, due to their poor economic status, have been forced to import western SE into their countries without testing its applicability. This observation is similar to Adas' (1989) view, which posits that there is an increasing tendency for most reforms in non-western SE to be inspired by uncritically imported western SE models. As such, the uncritical importation of SE practices from the western world has led to dysfunctionality and irrelevance in inherited educational programmes that were largely imported through colonialism (Lewin, 1990; McKinley \& Stewart, 2012).

At a classroom level such an importation has led to the science knowledge being presented abstractly and thus making it less interesting and irrelevant to the learners' experiences in non-western contexts. Fensham (2004) relates this practice to a process of disconnecting the 
non-western community from the expected SE experiences, a result which makes SE experiences being disconnected to the lives of non-western communities.

\subsection{Hegemonic impact of western science.}

This is a practice whereby there is total asymmetrical domination and subordination of non-western science practices by western science practices. At a classroom level in non-western context, this practice has forced the African child to absorb western science experiences during learning, despite their being largely irrelevant to individual life experiences (Anamuah-Mensah, 1998; Stewart, 2007). This practice has also left the majority of non-western SE learners being forced to discard their values and indigenous science knowledge and adopt the western ways of knowing and thinking (Manathunga, 2007). The increasing pressure among the non-western world has therefore been on adapting and accepting the science knowledge originating from the west, a practice that is viewed by education stakeholders from the non-western contexts as an imposition to the non-western ways of knowing.

\subsection{Oppressive impact of western science.}

The debates in SE identify the intellectually oppressive behaviors that western science has been perpetuating. The views by Penn (1997) and Dahlberg, Moss \& Pence, (1999) regarding the oppressive mentality of colonial education relate to what exists today in Tanzanian secondary education whereby students are still grouped in terms of family financial status, religion, and race. It is not surprising to see that there are still schools for white students whose experiences in these schools do not resemble those in black Tanzanian schools (i.e., the majority of Tanzanian schools). This practice not only weakens efforts to have common standards of schooling, but also presents a negative intellectual divide among students from the same country. As such, Lebakeng (2010) argues that African intellectuals (historians, anthropologists, sociologists, educationists, historians and philosophers) must subject indigenous science to "serious epistemological appraisal by resolving the theoretical, conceptual, methodological and philosophical issues about the identity of indigenous African knowledge systems and what their ontological, epistemological, axiological basis or foundations are as science knowledge" (p. 26).

\subsection{Disbelief and pessimism of western science.}

Western science as a culture has had a skeptical view towards non-western SE and has held an authoritative, dominant and repressive stance where its knowledge has not been questioned for authenticity or applicability in non-western contexts (Dei, 2012; Ogunniyi, 1996). Cobern and Loving (2001), and Ninnes and Burnett (2001) argue that western SE continues to present itself as Eurocentric, hegemonic, universal and humanity's most "powerful" and "best" (in the utilitarian sense) knowledge system for science. In this case, students from all learning backgrounds, irrespective of their diversity, are compelled to accommodate western science and to believe that it is the only option for them to be able to function competently in the mainstream of the global economy (Michie, 2003). Snively and Corsiglia (2001) look at this situation as a danger for SE; they insist on creating the balance 
between the two ways of knowing to avoid the educational alienation of students from their own culture. Dei (2012) adds that there is a need to develop indigenous perspectives from non-westerners through embedding their practices into their cultural contexts, histories and heritages.

Given these challenges this paper analyzes the voices and worldviews of silenced and excluded non-western SE practices for the sake of not only creating a conscious perspective of non-western contexts and culture, but also in order to enable students to move beyond false binaries, dualistic and/or essentialist views which suggest that there is one way of knowing science (Barton, Ermer, Burkett, \& Osborne, 2003; Keane, 2008; Ryan, 2008).

\section{Challenges of SE for non-western contexts}

The major challenge in today's world in SE is what to include and what to exclude for SE to be responsive both to the context and culture of the specific place (European Commission, 2004; ICASE, 2003; IOSTE, 2004). Although a specific strand for cultural issues has been developed at international conferences on SE, few have tackled the issues from the actual viewpoint of learners who are vividly living in non-western cultural contexts (Aikenhead, 2006). Despite the passionate rhetoric and interesting interventions, SE still appears to be experiencing challenges that can lead to six major crises, summarized below.

\subsection{Curriculum}

Most of today's non-western communities believe that the best future for non-western people lies with a rapid transition to western thinking, and that a more relevant curriculum would result in lower standards. In contrast, Knamiller (1984) argues that curriculum relevance should reflect a part of education that attempts to keep school children in touch with the common person, with their parents and their communities. It is unfortunate that the education system in most non-western contexts is characterized by teaching a wide range of subjects at the junior level of secondary education (up to age 19 in some schools). This has led to a more theoretical coverage of subject material. For example, learners have very little exposure to practical work in the laboratory, workshop or agricultural field; the learners leave school hardly able to do any useful work or solve any practical problems relating to their lives or to their environments (Ogunniyi, 1996). This situation has been contributed to by the fact that students are still taught science concepts from a Western European perspective. There is a need for a curriculum which aims at achieving the following goals: ability to adapt to the changing circumstances of a dynamic world; ability to develop skills of transforming chance events into opportunities; ability to develop sources of happiness; and ability to develop a readiness to act effectively for what is believed to be desirable (Fensham, 2004). Rollnick (1998) cements this call by insisting that SE lives up to the hope of improving society in the contexts in which it is offered.

\subsection{Books and learning materials}

Books and other learning materials that are culturally intended for schools, colleges and universities in Europe and North America have usually been used in African schools. Mugambi (2000) has asserted that ideally the publishing industry ought to support 
publications designed to meet the needs of the specific community. This has not been the case for most western publishing companies, because the western publishing industries have always contributed immensely towards alienation of the non-western learners from their own culture by providing texts that are not connected to experiences of the non-western communities. The arguments highlighted here are: How can African élite chart the future of the continent when its education is based on policies and ideas intended for other cultures? How can Africa's youth develop new insights to solve problems in the context of its own culture, while it is exposed only to literature coming from other cultures? These challenges call for a need for Africa's élite to re-shape the future of this continent through publication of the knowledge and experiences that are contextually and culturally responsive.

\subsection{The students' readiness}

The research studies reveal that most students in non-western contexts are generally attentive to their science lessons and spend a lot of time studying and looking for the right answers; yet a real understanding of subjects has appeared elusive to many (Odora-Hoppers, 2004). The researchers attribute this situation to having emanated from the unresponsiveness of SE to the cultural context of learners (Barton, Ermer, Burkett, \& Osborne, 2003). The focus of SE in non-western contexts has remained in the nature of the disciplines, rather than in the "nature and circumstances of the learner" (Ingle \& Turner, 1981, p.358). Many non-western students do not readily adopt the assumptions of problem solving and inquiry learning that underpin much western educational thinking. Instead, they often spend hours memorizing de-contextualized lists, formulae and teacher-directed procedures, activities which make little sense but which are seen by students and teachers as essential to the education process. Cobern and Loving (2001)argue that students in the non-western world have been complaining of the procedural and teaching/learning expectations of schools that leave them feeling like outsiders looking in, not really identifying with their education, but always expected to conform (Fleer, 2008). Ogunniyi (1988) argues that the difficulties that students experience in science are compounded by language and cultural issues in SE. Many researchers have attributed this problem to the methods of teaching in science subjects that often fail to link with the prior knowledge that the students have acquired from their different indigenous, scientific and mathematical cosmologies (Odora-Hoppers, 2004). The SE they receive, therefore, seems to encourage students to become uncritical consumers of the ideas, artifacts and life-styles of other societies, perhaps contributing to a breakdown of their vital cultural expectations (Lewin, 1993).

\subsection{English as a language of instruction in science classrooms}

Using English as the SE language of instruction in non-western contexts continues to frustrate the efforts of science educators and researchers. Most science educators agree that the greatest barrier to learning science in most non-western countries is language (McKinley\& Keegan, 2008). Using English as a language for science instruction has resulted in the majority of learners failing to comprehend what is written or taught and thus they resort to memorizing. It is an undeniable fact thatindigenous languages have been endangered due to the use of English as an official language of instruction in most schools in non-western 
countries since the 19th century (McKinley \& Keegan, 2008; Mugambi, 2000). Despite the initiatives, most schools in Africa use English right from primary school. The worst culprits are private elite nursery, primary and secondary schools that go to great lengths to produce children oriented towards English and western culture and totally alienated from their indigenous ways of knowing and their cultures. As a result, the students in developing countries have developed their feeling that school science is like a foreign culture to them (Maddock, 1981). Their feeling stems from fundamental cultural clashes between students' life-worlds and the world of western science as a culture of its own as noted by Keane (2008) and McKinley (2007).

\subsection{Assessment procedures in SE}

There has been the persistence of an attitude grounded in a long history in the west in which the achievements of SE in non-western communities have been judged with the standards of modern, western science and technology (Adas, 1989; McKinley \& Stewart, 2012). Studies argue that most national examination boards in non-western schools assume an ideal situation and set the same national exam without regard for the local conditions of learning in each school (Anamuah-Mensah, Mereku, \& Ameyaw-Asabere, 2004; Ogunniyi, 1996; Sjøberg, 2002). As coined by Ogawa $(1986,1989)$, some examination board seven go beyond adapting assessment frameworks whose origin is from the west, hence they end up interfering with great achievements in the whole process of SE.

\subsection{Science pedagogy}

Science knowledge in modern non-western contexts is presented as an established, certain, and non-challenged course of study which leaves no room for learners in these contexts to question its viability (Aikenhead, 1996; Snively \& Corsiglia, 2001). Learners from non-western countries would be capable of excelling well in science if they were given culturally appropriate instruction (Dei, 2012; Wilson, 1981). Culturally appropriate instruction would help students who are grounded in their tribe's traditional knowledge to clarify science concepts (ICASE, 2003; IOSTE, 2004). Unfortunately, many teachers do not recognize or value their students' cultural knowledge. When teachers neglect to affirm their students' traditional teachings nurtured in the home and local community, the students lose their desire to learn science, avoid science professions, and question their own cultural identity. As argued by Gay (2000), Osborne and Collins (2001) and Sjøberg and Schreiner (2002), it is therefore imperative that teachers and curriculum developers clearly develop SE policies that reflect learner-centred frameworks of pedagogy that are responsive to learners' needs and experiences.

\section{Way forward}

Following the way western SE has been defined in non-western contexts, this paper recommends that research results obtained from well-executed international studies could enhance the knowledge of what works best in different contexts, in terms of both cultural and contextual educational soundness and reality. While some attention is now being paid to 
education in science from a cross-cultural perspective, there is much more that needs to be done with respect to developing relevant cultural and contextual SE. For example:

- There is a need to thoroughly document and analyse imported knowledge in communities before attempts are made to use this knowledge in the classroom.

- Further strategies are needed for bridging the two ways of knowing, i.e., western science and traditional science must be developed and all strategies must be field-tested.

- It is important to continue to talk about the best ways to remedy this trend of cultural emptiness in African SE practices with a view to attaining a robust understanding of the situation.

- Indigenous African languages should be mounted as compulsory languages of instruction in African schools, not as curriculum lessons but as core courses.

- Instilling scientific culture in non-western communities should begin from their cultural attitudes towards local knowledge about their environment.

- African countries should be interested in only western experiences that fit well with their specific contexts; it is important and significant, for instance, that countries such as Taiwan, Korea, Indonesia, and Malaysia, which have chosen to de-emphasise foreign languages, ended up becoming great economies. At one time, India banned importation of western clothes; today, India is one of the largest producers of textiles in the world.

- Exchanging and sharing research findings among countries and international cooperation in doing research studies are important steps that the SE research community in the non-western contexts could take in the future; such efforts should be concerned with synthesizing and interpreting research for practitioners and the general public as well as for other researchers.

- It is important to redefine the current SE in non-western contexts to reflect the following aspects: Use of local resources; focusing on career awareness; providing opportunities to function in the community; and identifying ways that will have an impact in the future.

A general possible way forward to make SE contextually and culturally relevant to non-western communities could be by situating modern science as a "mirror", a model for the comparison to indigenous science, and from this model, multi-perspective science could be created within the expediencies of non-western communities. This includes a need for developing a comprehensive grand-design of SE enterprisewhich would support a change in the mission of school science in non-western contexts from students acquiring isolated bits of academic knowledge to students building a capacity to learn how to use Eurocentric science for everyday situations.

\section{Questions for further research}

These are some of the questions that arise from my research which require further investigation. The answers have the potential to inform SE for non-western countries. I am 
inviting other interested researchers to conduct further investigation on the following questions:

- Must African nations adapt science to the African context, exactly as the West has done?

- What is the implication of the importation of science programs from Euro-American countries into non-western (including African) countries? Is it a recipe for colonization?

- Is it possible for science to be taught without the cultural dress of the West?

- To what extent does western science inhibit the learning of scientific concepts in the non-western context?

- What cultural and contextual changes are necessary for effective science learning?

These questions arise because, relatively speaking, modern western science is a newly imported phenomenon in the cultures of most developing countries and it is implemented in the non-Western contexts for the interests of the west and for the most part, it is imported in western packaging.

\section{Reference:}

Adas, M. (1989).Machines as the Measure of man: Technology and Ideology of Western Dominance, Cornel University Press, Ithaka, NY

Aikenhead, G.S., \& Ogawa, M. (2007). Indigenous knowledge and science revisited. Cultural Studies of Science Education, 2(3), 539-620. http://dx.doi.org/10.1007/s11422-007-9067-8

Aikenhead, G. S. (1996). Science education: Border crossing into the subculture of science. Studies in Science Education, 27, 1-52. http://dx.doi.org/10.1080/03057269608560077s

Aikenhead, G. S. (2006). Science education for everyday life: Evidence-based practice. New York: Teachers CollegePress.

Anamuah-Mensah, J. (1998). Native science beliefs among Ghanaian students. Internal Journal of Science Education, 20(1), 115-124. http://dx.doi.org/10.1080/0950069980200108

Anamuah-Mensah, J., Mereku, D.K., \& Ameyaw-Asabere, A. (Eds) (2004). TIMSS 2003 Results from Ghanaian Junior Secondary 2 students. University of Education Winneba/Ghana Education Service, Inspectorate Division, Accra.

Anzaldua, G. (1999). Borderlands. Aunt Lute Books. San Francisco.

Barton, A. C., Ermer, M. L., Burkett, T. A., \& Osborne, M. D. (2003). Teaching science for social justice. New York: Teachers College Press.

Chapman, P.M. (2007). Traditional ecological knowledge (TEK) and scientific weight of evidence determinations. Marine Pollution Bulletin, 54, 1839-1840. http://dx.doi.org/10.1016/j.marpolbul.2007.10.033

Clandinin, D.J. (1993). Creating new spaces for women: Restoring teacher education. In D.J. Clandinin, A. Davies, P. Hogan \& B. Kennard (Eds). Learning to teach: Stories of 
collaboration in teacher education, pp.153-161.New York, Columbia University: Teachers College Press

Cobern, W.W. (Ed.) (1998). Socio-cultural perspective on science education. Dordrecht. The Netherlands: KluwerAcademic Publishers. http://dx.doi.org/10.1007/978-94-011-5224-2

Cobern, W. W., \& Loving, C. C. (2001). Defining "science" in a multicultural world: Implications for science education. Science Education, 85, 50-67. http://dx.doi.org/10.1002/1098-237X(200101)85:1<50::AID-SCE5>3.0.CO;2-G

Cooper, H. M. (1982). Scientific guidelines for conducting integrative research reviews. Review of Educational Research, 52, 291-302.

Dahlberg, G., Moss, P., \& Pence, A. (1999). Beyond quality in early childhood education and care: Postmodern perspectives. London: Falmer Press.

Davis, J., \& Martin, D. (2008). Racism, assessment, and instructional practices: Implications for mathematics teachers of African American students. Journal of Urban Mathematics Education, 1(1), 10-34

Dawson, C. (2000). Upper primary boys' and girls' interests in science: Have they changed since 1980? International Journal of Science Education, 22(6), 557-570. http://dx.doi.org/10.1080/095006900289660

Dei, G. J. S. (2012).Indigenous anti-colonial knowledge as 'heritage knowledge' for promoting Black/African education in diasporic contexts. Decolonization: Indigeneity, Education \& Society, 1(1), 102-119.

Ellul, J. (1990).The Technological Bluff. Wm. B. Eerdmans. European Commission. (2004). Increasing Human Resources for Science and Technology in Europe. Report presented at the conference 'Europe needs more scientists', Brussels

Fensham, P. J. (2004). Increasing the relevance of science and technology education for all students in the 21st century. Science Education International, 15(1), 7-26.

Fleer, M. (2008). A cultural-historical reading of culturally sensitive schooling: Thinking beyond a constructivist view of science learning. Cultural Studies of Science Education, 3(3), 781-786. http://dx.doi.org/10.1007/s11422-008-9114-0

Fredua-Kwarteng, Y., \& Ahia, F. (2005). Ghana flunks mathematics and science: Analysis (2). Retrieved July18, 2005, from

http://www.ghanaweb.com/GhanaHomePage/NewsArchive/artikel.php?ID=75906

Freire, P. (1999). Pedagogy of the oppressed. New York: Continuum.

Garrison, J.W., \& Bentley, M.L. (1990). Science education, conceptual change and breaking with everyday experience. Studies in Philosophy and Education, 10(1), 19-35. http://dx.doi.org/10.1007/BF00367685 
Gay, G. (2000). Culturally responsive teaching: Theory, research, and practice. New York: Teachers College Press.

Holbrook, J. (2003). The way forward. Science Education International, 14(1), 5-13.

Holbrook, J. (2010). Education through science as a motivational innovation for education for all. Science Education International, 21(2), 80-91.

ICASE (2003). Draft way forward document. ICASE: PenangIngle, R. B. \& Turner A. D. (1981), Mathematics and Chemistry, Education in Chemistry, 18(2) 48-51.

Ingle, R., \& Turner, A. (1981). Science curricula as cultural misfits. European Journal of Science Education, 3(4), 357-371. http://dx.doi.org/10.1080/0140528810304002

IOSTE, (2004).Science and technology education for a diverse World: Dilemmas, needs and partnerships. Retrived on June 21, 2012 from http://ioste11.umcs.lublin.pl/

Keane, M. (2008). Science education and worldview. Cultural Studies of Science Education, 3(3), 587-621. http://dx.doi.org/10.1007/s11422-007-9086-5

Kember, D. \& McNaught, C. (2007). Enhancing university teaching: Lessons from research into award winning teachers. Abingdon, Oxfordshire: Routledge.

Knamiller, G. W. (1984). The struggle for relevance in science education in developing countries. Studies in Science Education, 11, 60-78.

http://dx.doi.org/10.1080/03057268408559914

Lebakeng, T. G. (2010). Discourse on Indigenous knowledge systems, sustainable socio-economic development and the challenge of the academy in Africa. CODESRIA Bulletin, (1 \& 2) 24-29.

Lave, J., \& Wenger, E. (1991). Situated learning: Legitimate peripheral participation. Cambridge: Cambridge University Press. http://dx.doi.org/10.1017/CBO9780511815355s

Lewin, K. (1990).International perspectives on the development of science education: Food for thought. Studies in Science Education, 18, 1-23.

http://dx.doi.org/10.1080/03057269008559979

Lewin, K.M. (1993). Planning policy on science education in developing countries.

International Journal of Science Education, 15(1), 1-15.

http://dx.doi.org/10.1080/0950069930150101

Maddock, M. N (1981).Science education: An anthropological view Point. Studies in science education, 8, 1-2. http://dx.doi.org/10.1080/03057268108559884

Maddock, M. N (1983). Research into attitudes and science curriculum in Papua New Guinea. Journal of Science and Mathematics Education in South East Asia, 6(1), 23-35

Magubane. Z. (2004). Bringing the empire home: Race, class, and gender in Britain and colonial South Africa. Chicago. 
Manathunga, C. (2007). Unhomely academic developer identities: More post-colonial explorations. International Journal for Academic Development, 12(1), 25-34. http://dx.doi.org/10.1080/13601440701217287

Mbembe, A. (2001). On the post colony. Berkeley/Los Angeles, London: University of Califonia Press.

McKinley, E. (2007). Post colonialism, indigenous students, and science education. In S. K. Abell \& N.G. Lederman (Eds.), Handbook of Research in Science Education (pp. 199-226). Mahwah, NJ and London: Lawrence Erlbaum Associates.

McKinley, E., \& Keegan, P. (2008). Curriculum and language in Aotearoa: From science to Pūtaiao. L1- Educational Studies in Language and Literature, 8, 135-147.

McKinley, E., \& Stewart, G. (2012). Out of place: Indigenous knowledge in the science classroom. In B.J. Fraser et al (eds.), Second International Handbook of Science Education, pp. 541-554. Dordrecht: Springer. http://dx.doi.org/10.1007/978-1-4020-9041-7_37

McLellan, H. (1995). Situated learning perspectives. Englewood Cliffs, NJ: Educational Technology Publications

Michie, M. (2003). The role of culture brokers in intercultural science education: A research proposal. A Paper Presented at the Australasian Science Education Research Association Conference, Melbourne, Australia.

Mugambi, J. N. K. (2000). Challenges to publishers and writers of scholarly books intended for African readership. Academic Publishing and Book Distribution in Africa, Durban

Ninnes, P., \& Burnett, G. (2001). Postcolonial theory and science education: Textbooks, curriculum and cultural diversity in Aotearoa New Zealand. New Zealand Journal of Educational Studies, Te Hautaka Mätai Mätauranga, 36(1), 25 - 39.

Nyamnjoh, F. (2012). Potted plants in greenhouses: A critical reflection on the resilience of colonial education in Africa. Journal of Asian and African Studies, 1-26. http://dx.doi.org/10.1177/0021909611417240

Odora-Hoppers, C.A. (2001). Indigenous knowledge and the integration of knowledge systems: Towards a conceptual and methodological framework. Pretoria: HSRC.

Odora Hoppers, C.A. (2004). Culture, indigenous knowledge and development. A Paper Presented at Conference on Development Priorities and the Role of Tertiary Education, March 8-12, 2004, Wilton Park, UK.

Ogawa, M. (1986). Towards a new rationale of science education in a non-western society. European Journal of Science Education, 8, 113-119.

http://dx.doi.org/10.1080/0140528860800201

Ogawa, M. (1989). Beyond the tacit framework of "science" and "science education" among science educators. International Journal of Science Education, 11, 247-250. http://dx.doi.org/10.1080/0950069890110301 
Ogawa, M. (1995). Science education in a multi-science perspective. Science Education, 79, 593-593. http://dx.doi.org/10.1002/sce.3730790507

Ogawa, M. (2002). Nature of indigenous science: A stratified and amalgamated model of knowledge and cosmology. Paper Presented to the 33rd Annual Meeting of the Australasian Science Education Research Association, Townsville, Australia.

Ogunniyi, M. B (1996). Science, technology and mathematics: The problem of developing critical human capital in Africa. International Journal of Science Education, 18(3), 267-284. http://dx.doi.org/10.1080/0950069960180301

Ogunniyi, M.B. (1988). Adapting western science to traditional African culture. International Journal of Science Education, 10, 1-9. http://dx.doi.org/10.1080/0950069880100101

Osborne, J., \& Collins, S. (2001). Pupils' views of the role and value of the science curriculum: A focus group study. International Journal of Science Education, 23(5), 441-467. http://dx.doi.org/10.1080/09500690010006518

Osborne, J. F., Ratcliffe, M., Collins, S., Millar, R., \& Duschl, R. (2003). What 'ideas about science should be taught in school science? A Delphi Study of the 'Expert' Community.

Journal of Research in Science Teaching, 40(7), 692-720.

http://dx.doi.org/10.1002/tea.10105

Penn, H. (1997). Inclusivity and diversity in early childhood services in South Africa.

International Journal of Inclusive Education, 1(1), 101-114.

http://dx.doi.org/10.1080/13603116.1997.10384473

Porter, C., \& Parvin, J. (2009). Learning to love science: Harnessing children's scientific imagination. A report from the Chemical Industry Education Centre, University of York.

$\begin{array}{llll}\text { Retrieved June } & \text { 5, 2012, from }\end{array}$ http://www.static.shell.com/static/gbr/downloads/responsible_energy/ro1 427_ses_report.pdf

Prather, J. P. (1990). Tracing science teaching. Washington, DC: National Science Teachers Association.

Ryan, A. (2008). Indigenous knowledge in the science curriculum: Avoiding neo-colonialism. Culture Studies of Science Education, 3 (in press).

http://dx.doi.org/10.1007/s11422-007-9087-4

Ryder, J. (2001). Identifying science understanding for functional scientific literacy. Studies in Science Education, 36, 1-42. http://dx.doi.org/10.1080/03057260108560166

Rollnick, S. (1998b).Readiness, importance and confidence: critical conditions of change in treatment. In Treating Addictive Behaviors, 2nd edn, Miller, W. and Heather, N. eds, pp. 49-60. Plenum Press, London. http://dx.doi.org/10.1007/978-1-4899-1934-2_4

Roth, W.-M., \& Lee, S. (2004). Science Education as/for participation in the community. Science Education, 88, 263-291. 


\section{Macrothink}

Journal of Studies in Education

ISSN 2162-6952

2015, Vol. 5, No. 3

Sifuna, D. (2007). The challenges of increasing access and improving quality: An analysis of Universal Primary Education intervention in Kenya and Tanzania since 1970s. International Review of Education, 53, 687-699. http://dx.doi.org/10.1007/s11159-007-9062-z

Snively, G., \& Corsiglia, J. (2001). Discovering indigenous science: Implications for science education. Science Education, 85, 6-34.

http://dx.doi.org/10.1002/1098-237X(200101)85:1<6::AID-SCE3>3.0.CO;2-R

Stanley, W.B., \& Brickhouse, N.W. (2001). Teaching sciences: The multicultural question revisited. Science Education, 85(1), 35-49.

http://dx.doi.org/10.1002/1098-237X(200101)85:1<35::AID-SCE4>3.0.CO;2-6

Sjøberg, S., Schreiner, C. (2002). “ROSE Handbook”. Introduction, guidelines and under lying ideas. Retrieved on November 9, 2013 from

http://www.ils.uio.no/forskning/rose/documents/ROSE\%20handbook.htm

Stanley, M. (2007). Practical mystic: Religion, science, and A.S. Eddington. Chicago and London: University of Chicago Press.

Stewart, F. (2007). Policy issues for developing annuities markets. OECD Working Papers on Insurance and Private Pensions, No. 2, OECD Publishing.

Sjøberg, S. (2002). Science and technology education -current challenges and possible solutions. In: Sjøberg, S. (Ed). Three Contributions to Science Education. Acta Didactica, 2, 3-102.

Tillman, L. C. (2002). Culturally sensitive research approaches: an African-American perspective. Educational Researcher, 31(9), 3-12.

http://dx.doi.org/10.3102/0013189X031009003

UNESCO. (1993). Final report: International forum on scientific and technological literacy for all. Paris: Author.

Wilson, B.J. (1981). Cultural contexts of science and mathematics education. University of Leeds. Centre for Studies in Science Education, 8, 27-44. 